\title{
A new species of Caprella (Crustacea: Amphipoda: Caprellidae) from the landward slope of the Japan Trench
}

\author{
IChiro TAKeuchi $^{1,2,3, *}$, Masahiro Kihara ${ }^{1} \&$ Asako K. Matsumoto ${ }^{4}$ \\ ${ }^{1}$ Graduate School of Agriculture, Ehime University, 3-5-7 Tarumi, Matsuyama, Ehime 790-8566, Japan \\ ${ }^{2}$ Center of Advanced Technology for the Environment, Graduate School of Agriculture, Ehime University, 3-5-7 Tarumi, Ma- \\ tsuyama, Ehime 790-8566, Japan \\ ${ }^{3}$ Australian Museum Research Institute, Australian Museum, 1 William Street, Sydney, NSW 2010, Australia \\ ${ }^{4}$ Planetary Exploration Research Center (PERC), Chiba Institute of Technology (Chitech), 2-17-1 Tsudanuma, Narashino, \\ Chiba 275-0016, Japan
}

Received 30 August 2018; Accepted 29 March 2019 Responsible Editor: Shigeaki Kojima

doi: $10.3800 /$ pbr. 14.124

\begin{abstract}
Caprella hakuhoae sp. nov. (Crustacea: Amphipoda: Caprellidae) is herein described based on specimens collected from the landward slope of the $522 \mathrm{~m}$ deep Japan Trench, in the northwestern Pacific Ocean. This species is closely related to Caprella fimbrillata Vassilenko, 1993, recorded from the continental slope (605-1200 m) of the Chishima/Kuril-Kamchatka Trench, also in the northwestern Pacific Ocean. Caprella hakuhoae sp. nov. is distinguished from C. fimbrillata by the lack of paired mid-dorsal projections on pereonite 2, the presence of paired dorsal projections on pereonite 6 , the presence of two pairs of dorsal projections on pereonite 7 , and the merus being shorter than the propodus on pereopod 7 .
\end{abstract}

Key words: Amphipoda, Caprella, landward slope, new species, North West Pacific, taxonomy

\section{Introduction}

The research cruise KH-07-03 leg2 of the R/V HakuhoMaru (Ocean Research Institute, the University of Tokyo) to the landward slope of the Japan Trench, off the coast of northern Japan, was conducted to study the tomography of the subduction zone in the northeastern Japan forearc region (Yamamoto et al. 2008, 2014). During this cruise, three specimens from the genus Caprella (Crustacea: Amphipoda: Caprellidae) were found in association with the Ocean Bottom Seismograph (OBS), which was retrieved after approximately one year on the sea floor. Caprella is one of the most diverse genera of Amphipoda and most species in this genus inhabit shallow waters; the occurrence of specimens at over $300 \mathrm{~m}$ depth is rather rare. In this paper, the specimens collected during the cruise are described as a new species of Caprella (Amphipoda: Caprellidae).

\footnotetext{
*Corresponding author: Ichiro Takeuchi; E-mail, takeuchi@agr.ehimeu.ac.jp
}

\section{Materials and Methods}

During KH-07-03 leg2, a series of free-fall/pop-up type OBSs were recovered after surfacing from the stations off Miyagi Prefecture in the northwestern Pacific Ocean. Three specimens of caprellid amphipods attached to branching benthic Hydrozoan (Cnidaria; Hydrozoa; Hydroidolina) were collected from the surface of the OBS at St. S01, located on the landward slope of this region (Fig. 1). The collected specimens were preserved in $80 \%$ ethanol.

Figure plates were prepared primarily following Takeuchi (2015), which combined hand-drawn figures with digital inking. The original pencil sketches of the whole body in lateral view, antennae, and gnathopod 2 were drawn under a microscope equipped with a camera lucida. Mouthparts, gnathopod 1, and pereopods 5-7 of the described individual were dissected, mounted on slides in polyvinyllactophenol, and drawn under a microscope equipped with a camera lucida. Hand-inked sketches were drawn based on reduced copies of the original sketches using mapping pens, and then converted into digital files using Adobe Photoshop CS6 (Adobe Systems Incorporated, San Jose, 

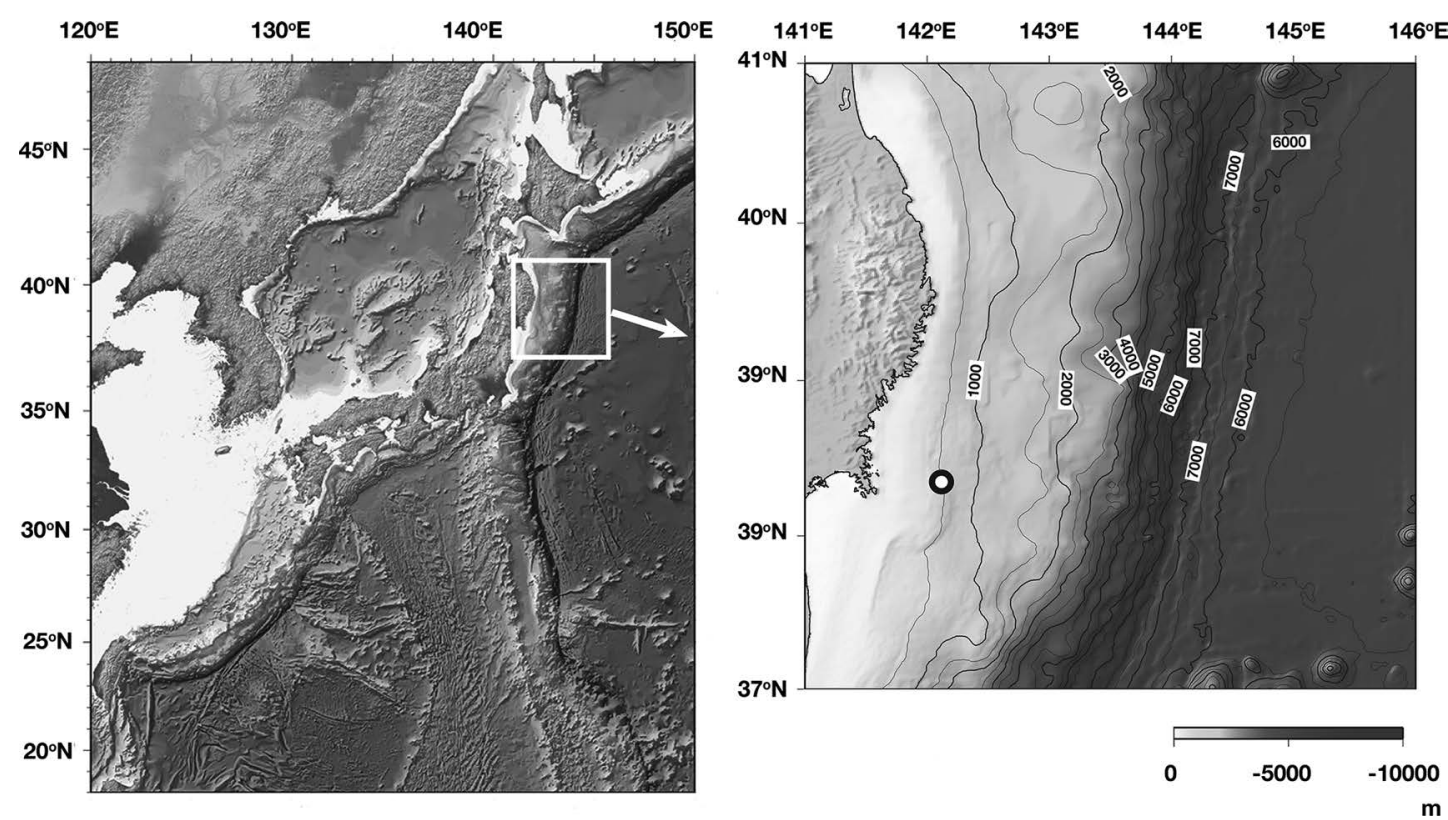

Fig. 1. Sampling site of Caprella hakuhoae sp. nov., at the landward slope of the Japan Trench, North Pacific. The bathymetric map of Japan (left) was provided by the Marine Information Research Center, Japan Hydrographic Association.

CA, USA). The familial classification proposed by Takeuchi (1993) was followed in the present study. The terminology of female stages for Caprella spp. follows Takeuchi and Hirano (1991). All materials were deposited in the National Museum of Nature and Science (NSMT-Cr), Tsukuba, Ibaraki, Japan or in the Australian Museum (AM), Sydney, New South Wales, Australia.

\section{Taxonomy}

\section{Family Caprellidae Leach, 1814 \\ Genus Caprella Lamarck, 1801}

\section{Caprella hakuhoae sp. nov.}

Figs. 2-4

Material examined-Holotype, male, NSMT-Cr 25903, $38^{\circ} 21.0342^{\prime} \mathrm{N}, 142^{\circ} 06.9910^{\prime} \mathrm{E}, 522 \mathrm{~m}$ depth, 9 Nov 2007, hydroids attached to OBS, R/V Hakuho-Maru, KH07-03 leg.2 St. S01. Paratype, 1 premature female, NSMT-Cr 25904, collected with the holotype. Paratype, 1 premature female, AM P.102596, collected with the holotype.

Type locality-landward slope of the Japan Trench; $38^{\circ} 21.0342^{\prime} \mathrm{N}, 142^{\circ} 06.9910^{\prime} \mathrm{E}, 522 \mathrm{~m}$ depth (Fig. 1).

Description-Holotype (Fig. 2), male, NSMT-Cr 25903, body length $18.48 \mathrm{~mm}$. Head $1.07 \mathrm{~mm}$, round fused with pereonite 1; eye distinct. Length of pereonites 1-7 $1.64 \mathrm{~mm}, 4.14 \mathrm{~mm}, 3.27 \mathrm{~mm}, 3.28 \mathrm{~mm}, 3.19 \mathrm{~mm}, 1.03 \mathrm{~mm}$, $0.86 \mathrm{~mm}$, respectively. Pereonite 4 with round postero-lateral projection. Pereonite 5 with small antero-lateral projection, postero-lateral projection, and paired mid-dorsal projections. Pereonite 6 with paired mid-dorsal projections. Pereonite 7 with paired mid-dorsal and postero-dor- sal projections.

Antenna 1 (Fig. 2) $0.65 \times$ body length; peduncular article 2 longest, $1.8 \times$ article 1 ; article $30.65 \times$ article 2 ; flagellum $0.75 \times$ peduncular length with 19 articles; basal segment composed of 3 articles. Antenna 2 (Fig. 3) $0.5 \times$ antenna 1 length; peduncle article 1 to flagellum article 1 setose.

Mouthparts (Fig. 4). Upper lip wider than deep, bilobed, setose. Lower lip, inner lobe round. Mandible right incisor with 5 teeth, lacinia mobilis with 3 teeth followed by 2 bounded setose, molar distinct with molar flake and 1 long seta. Mandible left incisor with 5 teeth, lacinia mobilis with 5 teeth followed by 3 bounded setose, molar distinct. Maxilla 1 outer plate with 7 stout apical setal-teeth; palp 2-articulate; article $24.5 \times$ article 1 with 10 lateral robust or slender setae and single line of apical stout setae. Maxilla 2 inner plate, oval, with ca. 15 setae; outer plate with ca. 15 apical setae. Maxilliped inner plate (basal endite) with 2 stout setae on inner half of distal margin, with a line of setae on entire distal margin; outer plate (ischial endite) $1.5 \times$ inner plate (basal endite) with ca. 20 setae on inner margin; palp 4-articulate, article 2 longest, setose along entire inner margin; article $31.5 \times$ article 1 , setose on lateral to distal part; dactylus falcate.

Gnathopod 1 (Fig. 3) basis, $1.2 \times$ ischium, merus, carpus combined; carpus subtriangular, densely setose; propodus triangular, length $1.5 \times$ width, setae on lateral part; palm begins at posterior margin; proximal projection equipped with a pair of robust setae (grasping spine) followed by ca. 25 setae along palm; dactylus falcate. Gnathopod 2 (Figs. 2, 3) begins $2 / 5$ along posterior margin of pereonite 2; basis $0.7 \times$ pereonite 2 length, with distal triangular projection; ischium $0.1 \times$ basis, with distal trian- 


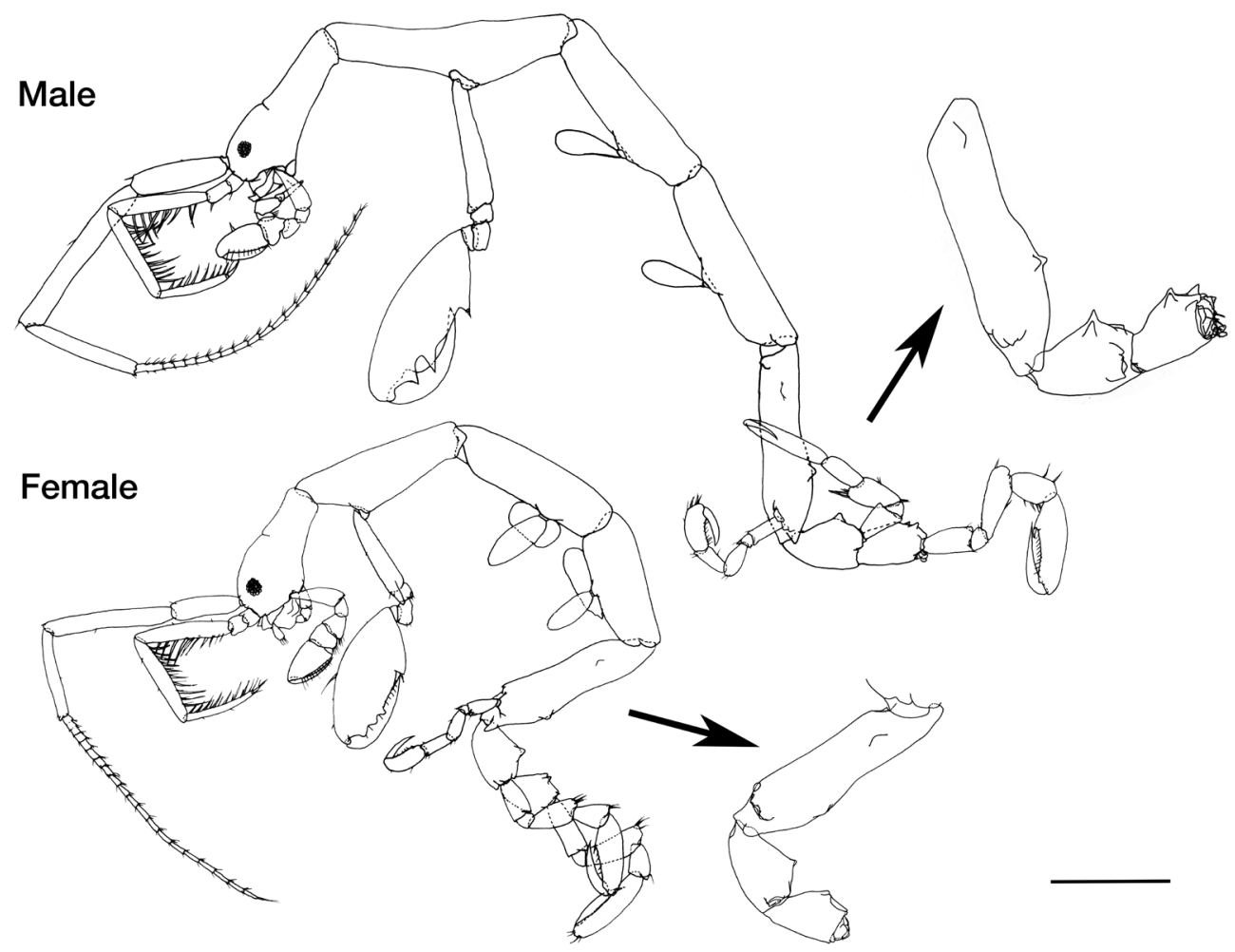

Fig. 2. Caprella hakuhoae sp. nov., holotype, male, NSMT-Cr 25903, $18.48 \mathrm{~mm}$, and paratype, female, NSMT-Cr 25904, $14.62 \mathrm{~mm}$, collected from the landward slope of the Japan Trench, North Pacific. Scale bar: $2.0 \mathrm{~mm}$.

gular projection; propodus longer than wide (length $2.2 \times$ width); palm begins $2 / 5$ along posterior margin, proximal projection with single robust seta (grasping spine) followed by 1 normal seta; palm with triangular projection near anterior end with shallow sinus, single row of small teeth between proximal projection.

Gill 3 (Fig. 2) length $0.3 \times$ pereonite 3, elongate; gill 4 subequal with gill 3.

Pereopod 5 (Fig. 3) basis $0.7 \times$ propodus, with small distal projection; ischium $0.2 \times$ basis; merus $1.2 \times$ basis; carpus $0.90 \times$ basis, setose along inner margin; propodus longest, with paired spines (grasping spines) 0.25 from posterior margin on palm followed by ca. 15 setae; dactylus falcate. Pereopod 6 longer than pereopod $5(1.3 \times$ longer). Pereopod 7 longer than pereopod $6(1.3 \times$ longer $)$.

Penis (Fig. 3) elongated. Uropod 1 peduncle short (length $1.3 \times$ width); ramus shoehorn-like, $1.7 \times$ peduncular length, with 3 lateral setae. Uropod 2 vestigial with 5 setae. Telson small, with pair of minute setae.

Paratype (Fig. 2), premature female, NSMT-Cr 25904, body length $14.62 \mathrm{~mm}$. Head $1.11 \mathrm{~mm}$. Length of pereonites $1-70.93 \mathrm{~mm}, 2.86 \mathrm{~mm}, 2.97 \mathrm{~mm}, 2.34 \mathrm{~mm}, 2.72 \mathrm{~mm}$, $0.90 \mathrm{~mm}, 0.78 \mathrm{~mm}$, respectively. Pereonite 5 with small anterolateral round projection, postero-lateral projection, and minute paired mid-dorsal projections. Pereonite 6 with paired mid-dorsal projections. Pereonite 7 with paired mid-dorsal and postero-dorsal projections.

Antenna $10.65 \times$ body length; peduncular article 2 lon- gest; flagellum subequal to peduncular length with 19 articles; basal segment composed of 3 articles. Gnathopod 2 begins $1 / 5$ along anterior margin of pereonite 2 ; basis 0.55 $\times$ pereonite 2 length; propodus longer than wide (length $2.2 \times$ width); palm begins $1 / 3$ along posterior margin; palm with shallow triangular projection. Uropod 1 vestigial with 2 setae. Uropod 2 vestigial.

Etymology-The species name, hakuhoae, is derived from the R/V Hakuho-Maru.

Remarks-Caprella is one of the largest genera in the order Amphipoda and is widely distributed in temperate regions (Takeuchi et al. 2001). To date, 183 species of this genus have been registered in the World Register of Marine Species (WoRMS) (Horton et al. 2018). Japan and adjacent areas have the highest species diversity of caprellids in the world (McCain \& Steinberg 1970; Takeuchi 1999), and $\sim 75$ species from this genus have been recorded to date (Mori 1999; Takeuchi 1999; Guerra-Garcia \& García-Gómez 2003; Aoki \& Ito 2012; Takeuchi \& Oyamada 2013). Most Caprella spp. from this region inhabit shallow waters (Takeuchi et al. 2001), but four species from a depth of over $300 \mathrm{~m}$ have been reported in this area (Arimoto 1934, 1976; Takeuchi et al. 1989; Guerra-García \& GarcíaGómez 2003; Lindsay \& Takeuchi 2008). Arimoto (1934) reported six species from the genus Caprella collected from the continental shelf off the Tohoku District, northeastern Japan, in 1926-1929, but did not provide collection information, including the depth of the collection sites. 


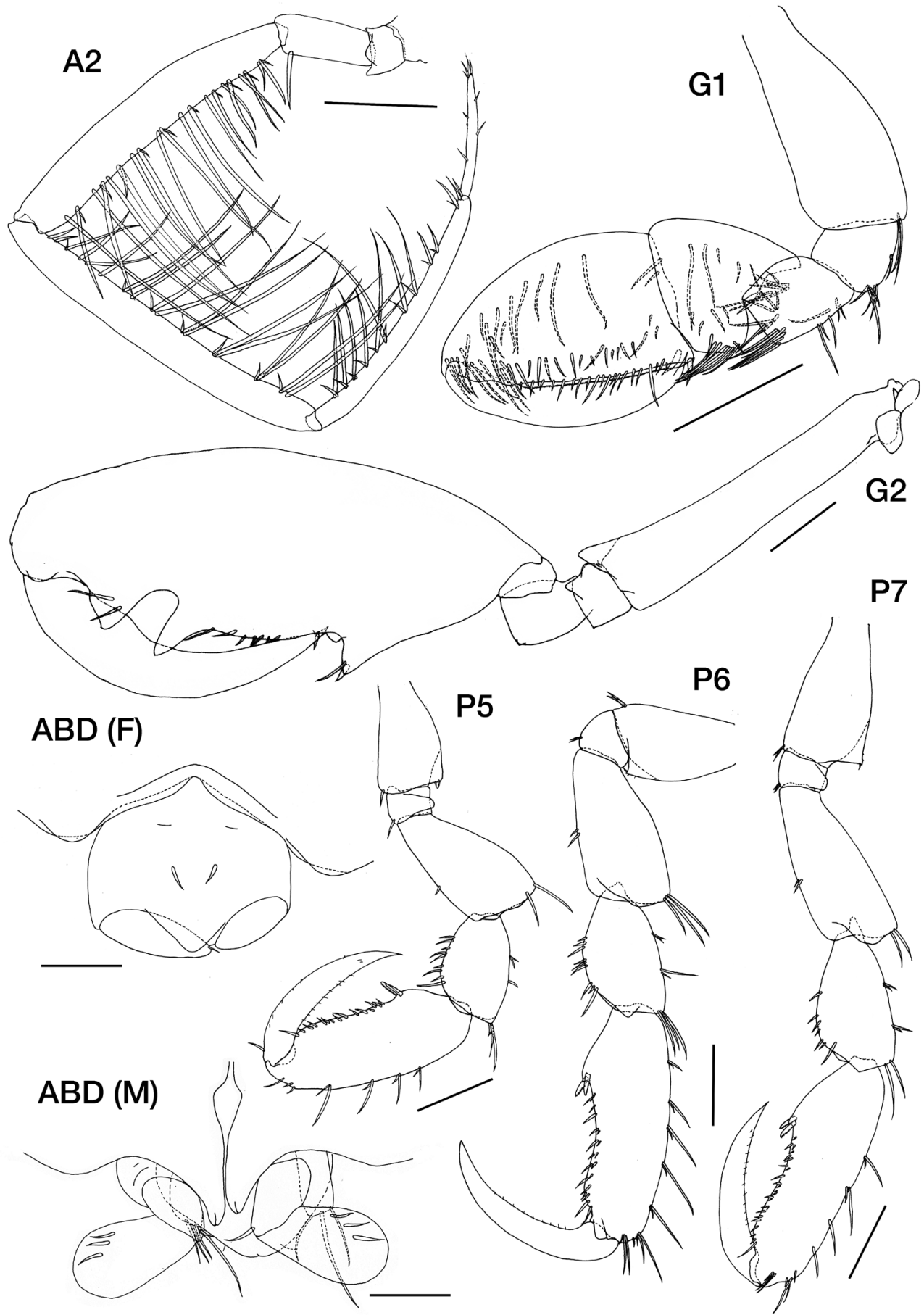

Fig. 3. Caprella hakuhoae sp. nov., holotype, male, NSMT-Cr 25903, $18.48 \mathrm{~mm}$, and paratype, female, NSMT-Cr 25904, $14.62 \mathrm{~mm}$, collected from the landward slope of the Japan Trench, North Pacific. A, antenna; ABD, abdomen; F, female; G, gnathopod; M, male; P, pereopod. Scale bars: $0.50 \mathrm{~mm}(\mathrm{~A} 2, \mathrm{G} 1, \mathrm{G} 2$, and P5-7), and $0.10 \mathrm{~mm}$ [in ABD (F) and ABD (M)].

Arimoto (1976) later reported that C. longidentata Arimoto, 1934 was collected from a sandy-mud bottom at a depth of $348 \mathrm{~m}$ off the Shizugawa Bay, Miyagi Prefecture $\left(38^{\circ} 27^{\prime} \mathrm{N}, 142^{\circ} 00^{\prime} \mathrm{E}\right)$, which is located $\sim 15 \mathrm{~km}$ northwest of the sampling site of the present study. The association of C. ungulina Mayer, 1903 with lithodid crabs (Lithodes aequispinus Benedict, 1895) from a depth of $\sim 400 \mathrm{~m}$ in the Suruga Bay and in the Sea of Okhotsk was reported
(Takeuchi et al. 1989). Caprella sabineae Guerra-García \& García-Gómez, 2003 was described based on specimens collected from a depth of $600 \mathrm{~m}$ depth in the Sagami Bay, Japan, during the Dr. Sixten Bock Japan Expedition in 1914. Lindsay \& Takeuchi (2008) reported the association of C. subtilis Mayer, 1903 with a swimming benthopelagic holothurian of the genus Ellipinion Hérouard, 1923 at a depth of $309 \mathrm{~m}$ in the Sagami Bay, Japan. Eleven species 


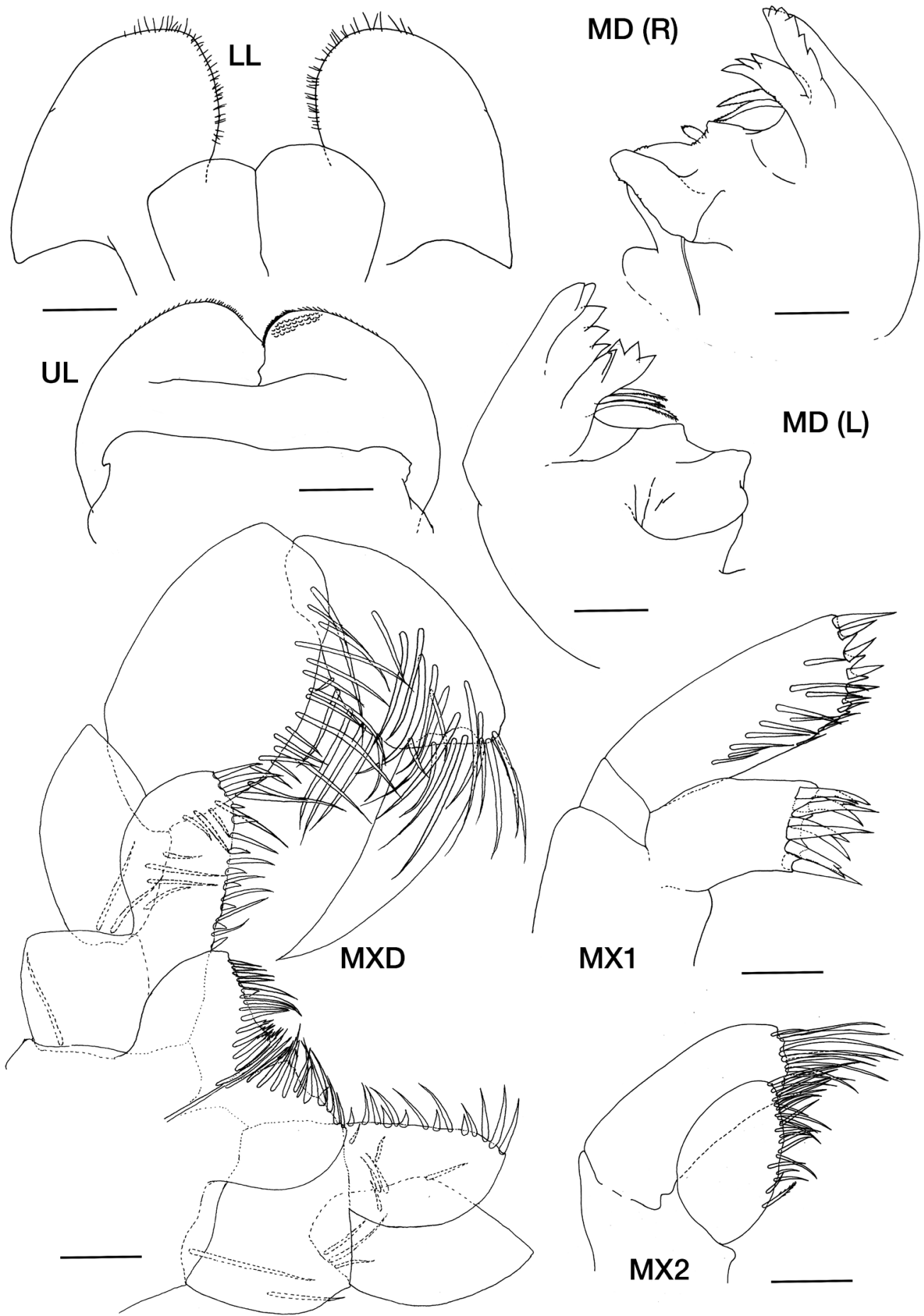

Fig. 4. Caprella hakuhoae sp. nov., holotype, male, NSMT-Cr 25903, $18.48 \mathrm{~mm}$, collected from the landward slope of the Japan Trench, North Pacific. L, left; LL, lower lip; MD, mandible, MX, maxilla; MXD, maxilliped; R, right; UL, upper lip. Scale bars: 0.10 mm.

from the genus Caprella were recorded from the continental slope of the Chishima/Kuril-Kamchatka Trench, located north of the Japan Trench, in the northwestern Pacific Ocean, at depths of 300-2200 m (Vassilenko 1993).

The presently described specimens of Caprella hakuhoae sp. nov. from the landward slope of the Japan Trench are morphologically similar to C. fimbrillata Vassilenko, 1993, which was discovered from the continen- tal slope (605-1200 m) of the Chishima/Kuril-Kamchatka Trench, also in the northwestern Pacific (Vassilenko 1993). Vassilenko (1993) described and illustrated three males and a mature female with ca. $10-40 \mathrm{~mm}$ and ca. $20 \mathrm{~mm}$ in body length, respectively. The present specimens from the Japan Trench were distinguished from C. fimbrillata based on the following characteristics: 1) in C. hakuhoae sp. nov., the combined length of the head and pereonite 1 was short- 
er than that of pereonite 2 , whereas in male C. fimbrillata it was equal to pereonite 2 ; 2) C. hakuhoae sp. nov. lacked small paired mid-dorsal projections on pereonite 2 , which were present in C. fimbrillata; 3 ) in male C. hakuhoae sp. nov., pereonites 5-6 had one pair of mid-dorsal projections, whereas in male $C$. fimbrillata these projections were absent; and 4) pereonite 7 of male C. hakuhoae sp. nov. had two pairs of dorsal projections, whereas these projections were absent in pereonite 7 of male C. fimbrillata. The aforementioned characteristics that separate these species are stable, at least in C. fimbrillata with a body length of $10-40 \mathrm{~mm}$. The body length of male holotype $C$. hakuhoae sp. nov. $(18.48 \mathrm{~mm})$ was within the range of that of C. fimbrillata. In addition to these differences, in pereopod 7 of male $C$. hakuhoae sp. nov., the merus was short ( $\times 0.8$ of propodus), whereas in the largest male $C$. fimbrillata the merus was long ( $\times 1.1$ of propodus). Caprella hakuhoae sp. nov. clearly differed from C. longidentata Arimoto, 1964 by lacking paired postero-dorsal projections on pereonite 1, paired mid-dorsal and postero-dorsal projections on pereonite 2, and numerous dorsal and lateral projections on pereonites 3-5.

Recently, Abyssododecas styx Takeuchi et al., 2016 was reported from cold-seep sites at abyssal depths (5313$7322 \mathrm{~m}$ ) in the Japan Trench, 175-265 km northeast of the sampling site of the present study (Takeuchi et al. 2016). Although A. styx resembles members of Caprellidae, it is more closely related to the genus Dodecasella K. H. Barnard, 1931, distributed in the Southern Ocean, from the family Phtisicidae. The results of the present study are consistent with the findings of Arimoto (1934, 1976) and Takeuchi et al. (2016), indicating that the distribution of Caprella spp. is limited to the continental shelf depth, whereas Abyssododecas inhabit bathyal to abyssal depths in the Japan Trench.

\section{Acknowledgements}

The authors express their sincere thanks to Prof. R. Hino (Research Center for Prediction of Earthquakes and Volcanic Eruptions, Tohoku University) for collecting the caprellid amphipods discovered on the Ocean Bottom Seismograph and providing the bathymetric map of the Japan Trench (Fig. 1, left), and to the Captain and crew of the R/V Hakuho-Maru for their continuous support during the collection of the materials studied onboard the KH-07-03 leg2 cruise of the R/V Hakuho-Maru.

\section{References}

Aoki MN, Ito A (2012) Caprella takedai, a new species of caprellid amphipod from off Ito, the east coast of Izu Peninsula, Shizuoka, Japan. In: Studies on Eumalacostraca: a Homage to Masatsune Takeda, Crustaceana Monographs Vol. 17 (eds Komatsu H, Okuno J, Fukuoka K), Brill, Leiden, the Netherlands, pp. 63-69.
Arimoto I (1934) Caprellidae (Crustacea) collected by T/S “Soyomaru”, Fisheries Training Institute, Ministry of Agriculture and Forestry. Dobutsugaku-zasshi (Zool Mag, Tokyo), 46 (553): 494-509.

Arimoto I (1976) Taxonomic studies of caprellids (Crustacea, Amphipoda, Caprellidae) found in the Japanese and adjacent waters. Spec Publ Seto Mar Biol Lab, Kyoto Univ 3: i-v + $1-229$.

Guerra-Garcia JM, García-Gómez JC (2003) A new species of Caprella (Amphipoda, Caprellidae) from deep sea waters. Crustaceana 76: 581-590.

Horton T, Lowry J, De Broyer C, Bellan-Santini D, Coleman CO, Corbari L, Daneliya M., Dauvin J-C, Fišer C, Gasca R, Grabowski M, Guerra-García JM, Hendrycks E, Hughes L, Jaume D, Jazdzewski K, Kim Y-H, King R, Krapp-Schickel T, LeCroy S, Lörz A-N, Mamos T, Senna AR, Serejo C, Sket B, Souza-Filho JF, Tandberg AH, Thomas J, Thurston M, Vader W, Väinölä R, Vonk R, White K, Zeidler W (2018) World Amphipoda Database. Caprella Lamarck, 1801. Accessed through: World Register of Marine Species at: http:// www.marinespecies.org/aphia.php? $\mathrm{p}=$ taxdetails $\& \mathrm{id}=101430$ on 2018-04-28

Lindsay DJ, Takeuchi I (2008) Associations in the deep-sea benthopelagic zone: the caprellid crustacean Caprella subtilis (Amphipoda: Caprellidae) and the holothurian Ellipinion $\mathrm{ku}$ mai (Elasipodida: Elpidiidae). Sci Mar 72: 519-526.

McCain JC, Steinberg JE (1970) Amphipoda I. Caprellidea I. Fam. Caprellidae. (eds Gruner H-E, Holthius LB), Crust Catal 2: 1-78.

Mori A (1999) Caprella kuroshio, a new species (Crustacea: Amphipoda: Caprellidae), with a redescription of Caprella cicur Mayer, 1903, and an evaluation of the genus Metacaprella Mayer, 1903. Proc Biol Soc Washington 112: 722-738.

Takeuchi I (1993) Is the Caprellidea a monophyletic group? J Nat Hist 27: 947-964.

Takeuchi I (1999) Checklist and bibliography of the Caprellidea (Crustacea: Amphipoda) from Japanese waters. Otsuchi Mar Sci 24: 5-17.

Takeuchi I (2015) A new species of Paraproto (Crustacea: Amphipoda: Phtisicidae) from the South Shetland Islands, Antarctica. Polar Sci 9: 368-373.

Takeuchi I, Hirano R (1991) Growth and reproduction of Caprella danilevskii (Crustacea: Amphipoda) reared in the laboratory. Mar Biol 110: 391-397.

Takeuchi I, Oyamada A (2013) Description of two species of Caprella (Crustacea: Amphipoda: Caprellidae) from the North Pacific; C. californica Stimpson, 1857 and C. scauroides Mayer, 1903, with a new appraisal of species ranking for C. scauroides. Helgoland Mar Res 67: 371-381.

Takeuchi I, Takahashi S, Tanabe S, Miyazaki N (2001) Caprella watch: a new approach for monitoring butyltin residues in the ocean. Mar Environ Res 52: 97-113.

Takeuchi I, Takeda M, Takeshita K (1989) Redescription of the bathyal caprellid, Caprella ungulina Mayer, 1903 (Crustacea, Amphipoda) from the North Pacific. Bull Nat Sci Mus (Tokyo) (Ser A, Zool) 15: 19-28.

Takeuchi I, Tomikawa K, Lindsay D (2016) A new genus and species of Phtisicidae (Crustacea: Amphipoda) from abyssal 
depths in the Japan Trench, with special reference to similarities with Southern Ocean genera. J Crust Biol 36: 495-506.

Vassilenko SV (1993) Caprogammarids and caprellids (Amphipoda, Caprellidea) of the continental slope of the Kurile Islands. Issledovaniya Fauny Morei 46: 130-155 (in Russian with English summary).

Yamamoto Y, Hino R, Suzuki K, Ito Y, Yamada T, Shinohara M, Kanazawa T, Aoki G, Tanaka M, Uehira K, Fujie G, Kaneda Y, Takanami T, Sato T (2008) Spatial heterogene- ity of the mantle wedge structure and interplate coupling in the NE Japan forearc region. Geophys Res Lett 35: L23304, doi:10.1029/2008GL036100.

Yamamoto Y, Obana K, Kodaira S, Hino R, Shinohara M (2014) Structural heterogeneities around the megathrust zone of the 2011 Tohoku earthquake from tomographic inversion of onshore and offshore seismic observations. J Geophys Res Solid Earth 119: 1165-1180. 